\title{
Evaluasi terhadap Konsep Desain Interior Ramah Lingkungan pada Lobby Lounge Boutique Hotel
}

\author{
Studi Kasus : Greenhost Boutique Hotel Yogyakarta
}

Fivanda

Universitas Tarumanagara

fivanda@fsrd.untar.ac.id

\begin{abstract}
Konsep desain yang beberapa tahun belakangan ini dikembangkan oleh desainer, arsitek dan pengusaha hotel umumnya mengedepankan konsep ramah lingkungan. Dibalik beberapa kesuksesan perkembangan hotel masa kini, konsumen memang lebih menggemari konsep desain hotel yang berhubungan dengan alam dan terkesan alami. Konsep ramah lingkungan sebagai salah satu wujud implementasi konsep pembangunan berkelanjutan dan merupakan salah satu langkah bagi masyarakat untuk ikut serta terhadap kepedulian lingkungannya. Konsep ramah lingkungan sekarang sudah mulai diterapkan pada hotel dari mulai budget hotel hingga boutique hotel. Greenhost boutique hotel Yogyakarta ini mengedepankan konsep ramah lingkungan pada keseluruhan interior, bangunan dan manajemennya. Konsep Sustainable (berkelanjutan) ini ditandai dengan adanya kestabilan, dimana perubahan-perubahan terus dibatasi untuk menjaga keseimbangan dari sistem pada masa depan. Ada tiga hal yang menjadi tujuan dari konsep yang sudah dicapai yaitu meminimalkan konsumsi bahan dan energi, mencegah efek negatif pada daya dukung lingkaran dan lingkungan itu sendiri serta memenuhi kebutuhan manusia. Adanya keseimbangan yang harmonis antara manusia sebagai pengguna dengan kebiasaan manusia serta lingkungan sehingga di masa depan dapat dicapai kesinambungan dan keseimbangan hidup. Selain itu, Konsep sustainable tidak hanya diterapkan pada peletakan pintu utama, bukaan alami jendela, pencahayaan alami tetapi juga terhadap furnitur dan material yang digunakan menghasilkan limbah daur ulang yang ramah lingkungan.
\end{abstract}

Kata Kunci : hotel, boutique hotel, konsep desain, sustainable design.

\section{PENDAHULUAN}

Perkembangan IImu dan Teknologi yang sangat pesat sekarang ini seringkali menimbulkan banyak dampak negatif terhadap lingkungan. Pembangunan mempengaruhi dan dipengaruhi oleh lingkungan sekitarnya. Prinsip-prinsip penghijauan pada fasilitas ruang publik perlu diterapkan dari sisi pemahaman konsep sustainable. Beberapa pendekatan konsep penghijauan dan berkelanjutan dalam bangunan publik (Tri Harso Karyono, 2013) yaitu dengan meminimalkan perolehan panas (heat gain) dari radiasi matahari pada bangunan seperti membuat dinding lapis berongga yang diberi ventilasi pada rongganya dan membuat ventilasi pada ruang antara atap dan langit-langit agar tidak terjadi akumulasi panas, serta memaksimalkan pelepasan panas dalam bangunan. Dalam perancangan konsep ruang publik perlu mempertimbangkan kenyamanan fisik dan kenyamanan termal serta memiliki ruang terbuka hijau pada lingkungan sekeliling untuk meningkatkan aliran udara. Prinsip penghijauan pada 
beberapa kota di Indonesia tampaknya sudah mulai diterapkan.

Seiring peningkatan jumlah wisatawan yang datang, kebutuhan pada akomodasi hotel yang merupakan tempat para wisatawan beristirahat pun ikut meningkat. Pilihan jenis hotel masa kini pun semakin banyak, yang diantaranya adalah boutique hotel. Boutique hotel menawarkan harga terjangkau dengan kenyamanan dan konsep desain yang unik. Berdasarkan pengamatan, pada umumnya boutique hotel memasukkan karakter tertentu dari suatu daerah tempatnya dibangun. Peningkatan jumlah wisatawan lebih memilih mendapatkan pengalaman baru dengan memilih hotel butik yang memiliki daya tarik tersendiri. Akan dapat menjadi daya tarik baru untuk wisatawan yang datang Yogyakarta terutama pelaku desain dan seni.

Boutique hotel pada dasarnya tidak mempunyai standarisasi minimum jumlah dan ukuran kamarnya. Hotel boutique menargetkan beberapa kota-kota yang menjadi destinasi wisata. Di Indonesia sendiri hotel boutique banyak ditemukan di Surakarta, Yogyakarta, Bali dan Bandung. Desainnya dibuat lekat dengan unsure budaya masyarakat setempat. Prinsip-prinsip hotel boutique pada umumnya (Lawson : 1999) :

- Penggunaan elemen-elemen perancangan yang tidak biasa seperti garis, warna, bentuk, tekstur, pola, ruang dan cahaya.

- Langgam arsitektur yang berbeda dari lingkungan di sekitarnya.

- Hotel berskala kecil yang memiliki gaya dan ciri khas tersendiri.

- Fokus terhadap gaya yang eksotis, keramahan dari keakraban serta pelayanan yang memuaskan.

- Unsur Teknologi pembangunan seperti konsep ecodesign juga sudah berkembang pada pembangunan hotel boutique sekarang ini.

Greenhost Hotel didirikan di Yogyakarta pada tahun 2014 oleh Paulus Mintarga, Ananda Soewono, serta Santo. Sejak awal Greenhost Hotel telah berkomitmen untuk keberlangsungan dan berkewajiban terhadap lingkungan dan masyarakat sekitar. Greenhost Boutique Hotel merupakan hotel boutique pertama yang ramah lingkungan di Indonesia dengan menawarkan fasilitas modern dengan sentuhan budaya lokal di lingkungan yang tenang dan ramah. 
Greenhost Hotel merupakan boutique hotel dengan konsep dan tempat yang dinamis. Konsep penggabungan perhotelan yang santai dengan pengalaman yang kreatif dalam bidang desain, seni, kerajinan dan kota pertanian Yogyakarta. Mengaplikasikan konsep sustainable dengan berbagai cara, sehingga memiliki gayanya tersendiri yang menjadi daya tarik hotel ini. Konsep Sustainable itu sendiri salah satunya diartikan oleh World Commision on Environment and Development tahun 1987 sebagai : "Pemenuhan kebutuhan pada saat sekarang tanpa merugikan generasi masa depan untuk memenuhi kebutuhan mereka". Konsep boutique hotel yang berkembang saat ini merupakan gagasan yang memadukan berbagai unsur kedalam suatu kesatuan. Unsur - unsur dari konsep ini dapat berupa gagasan, pendapat dan pengamatan.

\section{Konsep Sustainable (berkelanjutan)}

Greenhost Hotel ini lebih kepada tata letak layout bangunan, interior dan material furniture yang diterapkan. Dengan sebuah sistem yang ditandai dengan kestabilan, dimana perubahan-perubahan terus dibatasi untuk menjaga keseimbangan dari sistem pada masa depan. Dari gabungan semua konsep dasar dalam interior ada 3 hal yang menjadi tujuan konsep sustainable dasar yang ingin dicapai (Jong-Jin Kim : 1998) :

1. Meminimalkan konsumsi bahan dan energi.

2. Mencegah efek negatif pada daya dukung lingkaran dan lingkungan itu sendiri.

3. Memenuhi kebutuhan manusia.

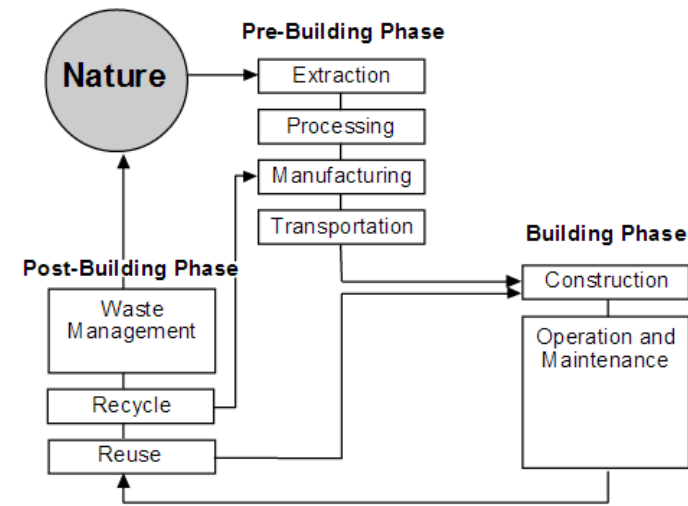

Gambar 1. The Sustainable Building Life Cycle (Jong-Jin Kim. Brend Rigdon. Sustainable Architecture Module : Introduction to Sustainable, 1998)

Konsep material ramah lingkungan memiliki kriteria :

1. Tidak beracun sebelum maupun sesudah digunakan.

2. Dalam proses pembuatannya tidak memproduksi zat-zat berbahaya bagi lingkungan.

3. Dapat menghubungkan manusia dengan alam, dalam arti pengguna semakin dekat dengan alam karena kesan alami dari material tersebut. 
4. Bisa didapatkan dengan mudah dan dekat (tidak memerlukan ongkos atau proses memindahkan yang besar, karena menghemat energi BBM untuk memindahkan material tersebut ke lokasi pembangunan).

5. Dapat terurai dengan mudah secara alami.

6. Mengandung prinsip Renewable, Reuse, Recycle, \& Reduce.

Melalui pertimbangan cermat pada dampaknya, bahwa sistem pengoprasian, material dan kebijakan terhadap lingkungan, hotel ini terus mengembangkan inisiatif dan prosedur baru untuk meminimalkan dampak ekologi dalam kelangsungan hidup manusia sebagai pengguna.

\section{METODE}

Penelitian ini mengambil objek penelitian yaitu Greenhost Boutique Hotel Prawirotaman, Yogyakarta dengan area penelitian mencakup tata layout bangunan dan interior diantaranya ruang lobby, area lobby lounge dan area restoran Art-Kitchen. Penelitian ini menggunakan teknik observasi dengan pengamatan langsung pada ketiga ruang dan area tersebut. Kemudian mendokumentasikan data visual berupa foto mengenai permasalahan yang sedang diteliti. Teknik observasi ini menghasilkan gambaran konkret mengenai aplikasi konsep sustainable dan penerapan konsep sustainable pada bahan material arsitektur serta interior.

Setelah proses pengambilan data dan observasi dilakukan, dilanjutkan pada tahapan analisa evaluasi kondisi interior dengan parameter material dan tata letak layout interior yang ramah lingkungan dengan pendukung studi literature. Teknik studi literatur ini digunakan untuk memperoleh landasan teori dan informasi yang dibutuhkan oleh peneliti.

\section{HASIL DAN PEMBAHASAN}

Lobby Lounge Greenhost

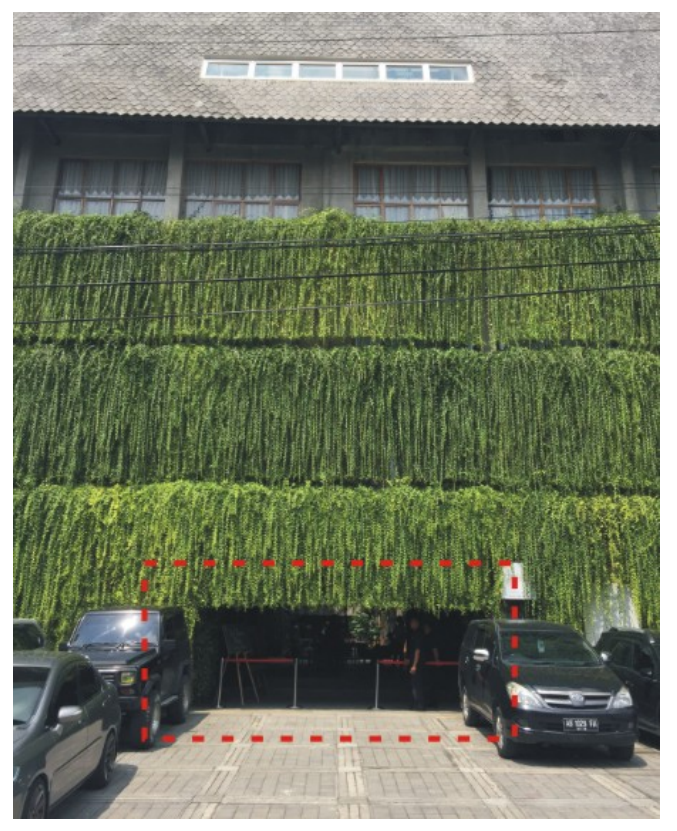

Gambar 2. Area Masuk ke Lobby dari Fasade Bangunan (Dokumentasi Pribadi, 2017) 
Area Lobby merupakan area publik yang menjadi ruangan pertama yang dimasuki oleh pengunjung. Area masuk lobby hotel Greenhost terletak di bagian depan tengah bangunan seperti terlihat pada Gambar 2

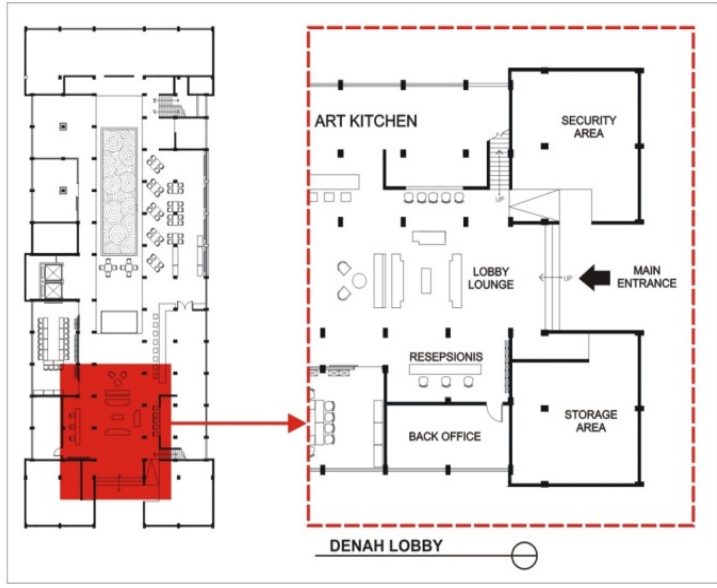

Gambar 3. Denah Lantai Dasar Area Lobby (Data Pribadi, 2017)

dan Gambar $\mathbf{3}$ area masuk ini merupakan area bukaan yang besar tanpa pintu dari fasade bangunan.

Pengunjung masuk melalui area tengah bangunan menuju lobby lounge yang terdiri dari kursi dengan material kayu dan besi. Di area tengah tersebut terdapat patung seorang anak kecil dengan tangan yang bertransformasi menjadi tanaman yang dihinggapi burung yang terbuat dari besi. Artwork patung ini menjadi icon utama di lobby yang menjadi ciri khas hotel Greenhost seperti terlihat pada Gambar 4.

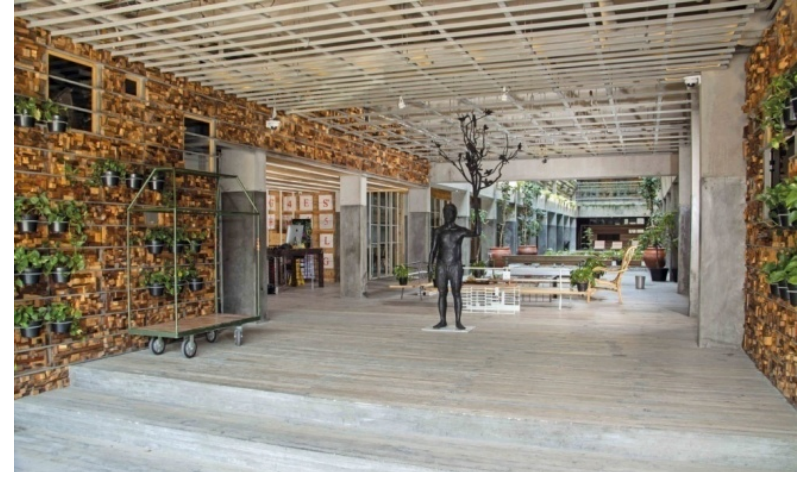

Gambar 4. Patung besi (Artwork Patung) pada area masuk Lobby Lounge

(Greenhost Hotel, 2017)

Ruangan kiri dan kanan pada area masuk merupakan ruangan privasi untuk security dan ruang penyimpanan untuk pengelola serta karyawan, sehingga dinding dibuat tertutup dengan partisi dan juga material olahan panel kayu jati sisa dengan rangka besi seperti pada Gambar 4 dan Gambar 5. Selain itu dinding partisi juga ditambahkan unsur tanaman yang digantung menggunakan besi sehingga memperkuat kesan alami dan ramah lingkungan.

Material lantai menggunakan beton ekspos dengan pola dan serat menyerupai kayu, sedangkan ceiling ekspos beton ditambahkan unsur rangka besi sebagai penguat aksen ruangan juga berfungsi sebagai penempatan pencahayaan tidak langsung (indirect) untuk pencahayaan umum buatan pada malam hari Gambar 5 . 


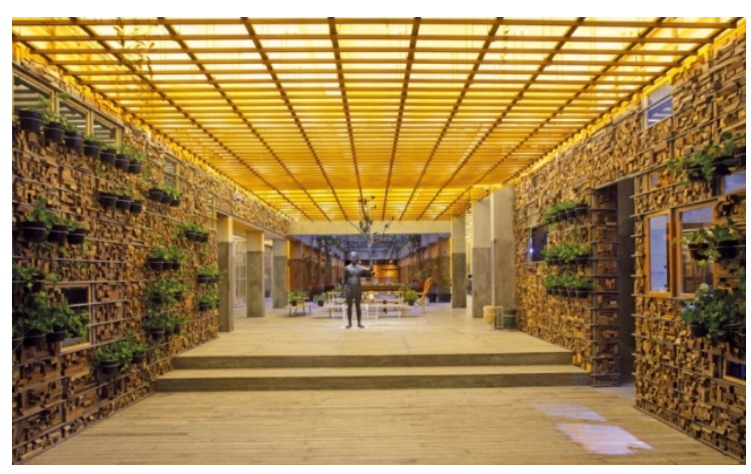

Gambar 5. Ekspos Ceiling dengan rangka besi sebagai penempatan pencahayaan buatan

(Greenhost Hotel, 2017)

Area lobby terdiri dari lobby lounge di tengah dan area resepsionis yang terletak di sebelah kiri dari area masuk utama (Gambar 5 dan Gambar 6). Dinding pada area resepsionis masih menggunakan partisi tertutup untuk membatasi area back office yang lebih privasi dengan menggunakan rangka besi dan panel lembaran kayu pinus (warna kuning muda) yang membedakan area resepsionis dengan area masuk (kayu jati/coklat). Dengan ceiling yang lebih rendah untuk membuat fokus ruangan pada meja resepsionis seperti terlihat pada Gambar 6.

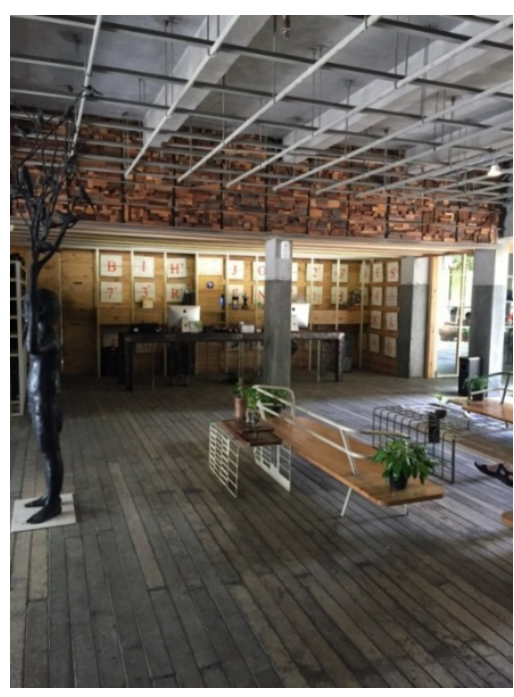

Gambar 6. Area Resepsionis dan Lobby Lounge (Dokumentasi Pribadi, 2017)

Bangunan yang ramah lingkungan di hadirkan dengan penggunaaan materialmaterial bekas pakai yang diupcycle. Pada salah satu sudut tampak depan bangunan hotel ini sudah terasa penggunaan material upcycle dengan penggunaan kayu bekas yang dijadikan pembalut dinding.

Pemilihan material pada furnitur area lobby mengikuti konsep arsitektur dan elemen desain interior dengan menggunakan kombinasi besi dan kayu. Seperti pada meja resepsionis dan juga furniture lobby lounge (kursi dan meja). Penggunaan material ini memperkuat konsep ramah lingkungan karena kayu yang digunakan merupakan kayu-kayu sisa olahan yang dengan dimensi yang kecil dan digabungkan menjadi panel press. Seperti terlihat pada Gambar 7 dan

\section{Gambar 8.}




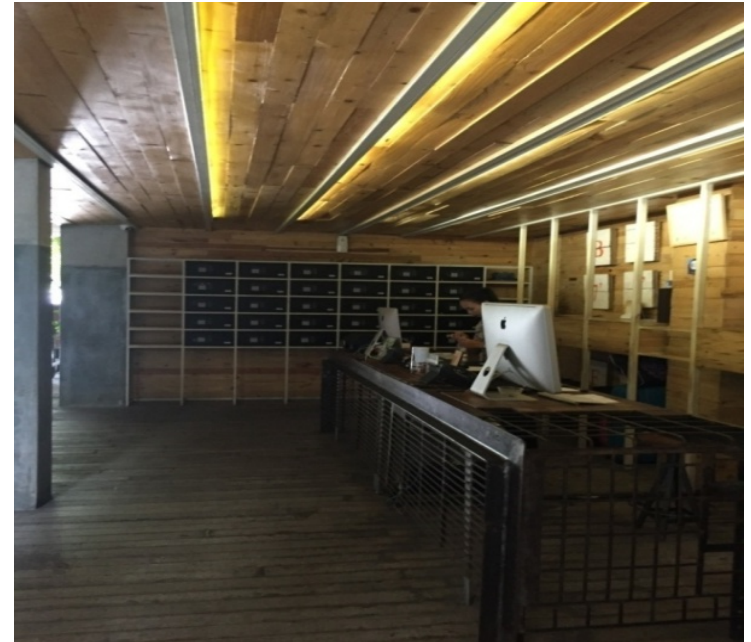

Gambar 7. Furniture pada Area Resepsionis (Dokumentasi Pribadi, 2017)

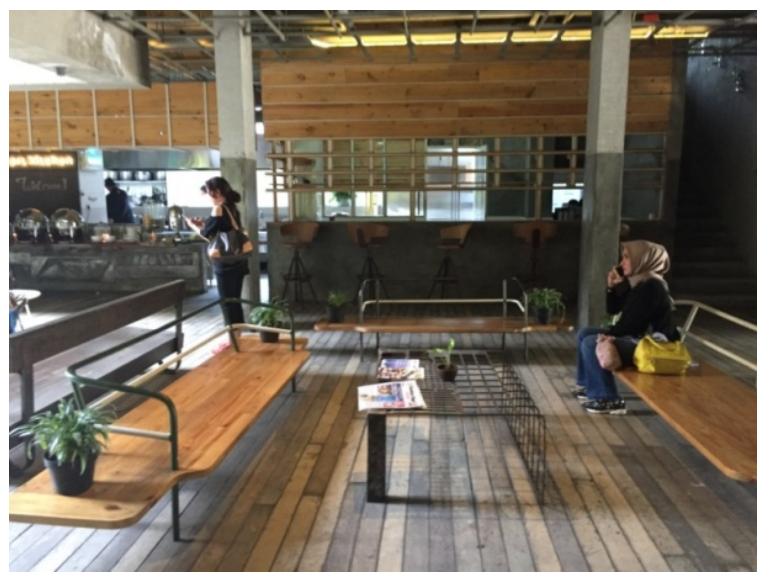

Gambar 8. Furniture pada Area Lobby Lounge (Dokumentasi Pribadi, 2017)

Secara keseluruhan penggunaan material interior dan pemilihan furniture pada area lobby masih mengacu pada konsep ramah lingkungan bangunan. Elemen aristektur menjadi dominan dengan material beton ekspos pada dinding, kolom dan ceiling. Elemen dinding interior ditambahkan unsur kayu dan besi, begitu juga dengan elemen ceiling yang menggunakan rangka besi untuk aksen ruang dan berfungsi sebagai penempatan lampu. Material lantai pada area lobby juga menggunakan ekspos beton yang dibuat dengan pola dan serat kayu. Furniture juga didesain sesuai dengan konsep ramah lingkungan dengan menggunakan material kayu dan besi. Data penggunaan material elemen interior dan furniture dapat dilihat melalui diagram pada Gambar 9.

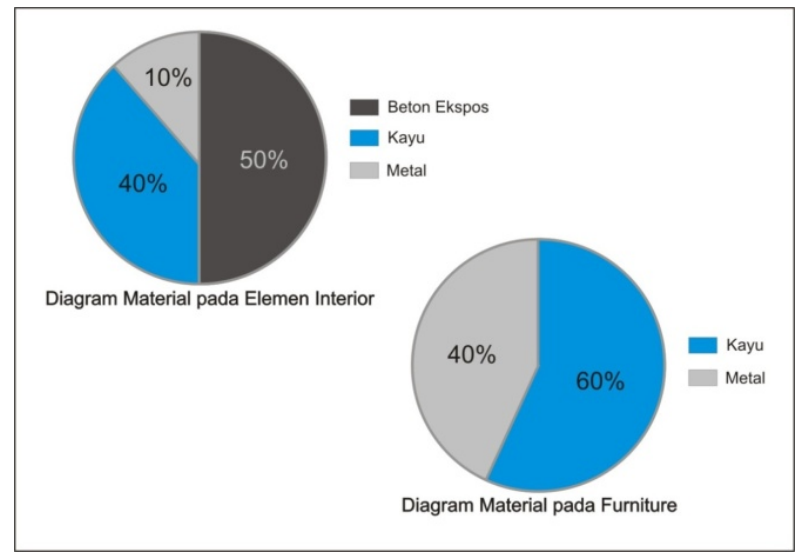

Gambar 9. Diagram penggunaan material ramah lingkungan pada elemen interior dan furniture area lobby lounge (Data Pribadi, 2017)

Diagram lingkaran diatas dibuat berdasarkan jumlah material pada elemen ruang dan furniture yang ada pada Lobby hotel Greenhost. Elemen interior (lantai, dinding, ceiling) menggunakan material beton $50 \%$, kayu $40 \%$ dan besi $10 \%$. Sedangkan furniture menggunakan material kayu sebanyak $60 \%$ dan $40 \%$ menggunakan material metal.Dengan adanya data tersebut dapat disimpulkan material ramah lingkungan yang paling banyak digunakan 
pada lobby hotel Greenhost adalah beton ekspos dan kayu.

\section{KESIMPULAN}

Tampilan depan Greenhost Boutique Hotel, nuansa green konsep sudah terasa dengan adanya tanaman-tanaman rambat yang menghiasi fasad bangunan. Koridorkoridor kamar diberikan tanaman hidroponik sebagai sentuhan hijau dan segar. Diyakininya dengan adanya tanaman tersebut, kesan keras dan panas bangunan modern akan berganti menjadi sebuah bangunan ramah lingkungan. Konsep elemen interior pembentuk ruangan semua area di Greenhost Hotel ini mengusung tema unfinished dalam pengertian penerapan material yang semua masih dalam taraf setengah jadi seperti acian semen berwarna abu-abu sebagai upaya untuk mengurangi penggunaan cat yang berlebihan. Untuk sistem listrik dan air juga demikian dihimbau untuk tidak menyalakan apabila sedang tidak digunakan.

Konsep kestabilan dan berkelanjutan ini yang sudah diterapkan dalam Greenhost Boutique Hotel dari aspek-aspek :

a. Konsep bangunan hijau dengan posisi bangunan berada di tengah area sehingga menjadi pusat dari udara dan gerak manusia sebagai pengguna serta penghargaan terhadap alam

b. Konsep Interior yang memiliki sirkulasi gerak dan udara ideal dengan perpaduan gaya dan tema yang mendukung konsep green

c. Konsep Furniture yang mendukung konsep interior dengan mengedepankan penggunaan material yang ramah lingkungan seperti kayu upcycle serta material yang rendah kadar limbah yang dihasilkan dan mudah direcycle serta digunakan kembali (reuse)

d. Konsep pencahayaan dan penghawaan yang meminimalkan penggunaan energi di pagi, siang dan malam hari. Mengoptimalkan penggunaan energi alami.

\section{DAFTAR PUSTAKA}

Bauer, Micheal. 2007. Green Building Guidebook for Sustainable Architecture, Germany : Springer Heidelberg Dordrecht london : New York. Jin Kim, Jong. 1998. Sustainable Architecture Module : Introduction to Sustainable Design, USA : The University of Michigan.

Karyono, Tri Harso. 2010. Green

Architecture: Pengantar Pemahaman 
Arsitektur Hijau di Indonesia, Jakarta:

Penerbit PT Raja Grafindo Persada.

Karyono, Tri Harso. 2013. Arsitektur dan

Kota Tropis Dunia Ketiga : Suatu

Bahasan tentang Indonesia, Jakarta:

Penerbit PT Raja Grafindo Persada.

Lawson, Fred. 1999. Hotels \& Resorts,

Planning, Design and Refurbishment,

Architectural Press : Oxford. 